\title{
PopP1, a New Member of the YopJ/AvrRxv Family of Type III Effector Proteins, Acts as a Host-Specificity Factor and Modulates Aggressiveness of Ralstonia solanacearum
}

\author{
Muriel Lavie, ${ }^{1}$ Edwin Shillington, ${ }^{2}$ Cédric Eguiluz, ${ }^{1}$ Nigel Grimsley, ${ }^{1}$ and Christian Boucher ${ }^{1}$ \\ ${ }^{1}$ Laboratoire de Biologie Moléculaire des Relations Plantes-Microorganismes, INRA-CNRS, BP27, 31326 Castanet-tolosan \\ Cedex, France; ${ }^{2}$ Groupe de cristallographie biologique, Institut de Pharmacologie et de Biologie Structurale, CNRS, 205 \\ route de Narbonne, 31077 Toulouse Cedex, France
}

Submitted 17 June 2002. Accepted 18 June 2002.

\begin{abstract}
A functional analysis of an 11-kb-long region of the genome of the plant-pathogenic bacterium Ralstonia solanacearum, previously identified as an alternative codon usage region (ACUR), reveals that it was probably acquired through horizontal gene transfer. This ACUR encodes an insertion sequence and eight potential proteins, one of which is partially homologous with a host-specificity factor from a plant-pathogenic Erwinia sp., and another, PopP1, which is homologous to members of the YopJ/AvrRxv family of type III-secreted bacterial effectors controlling interaction between bacteria and their hosts. The analysis of mutants affecting all except one of the genes identified in the ACUR showed that only the popP1-deficient strain had an altered phenotype in plant infection tests. This mutant strain became pathogenic to a Petunia line that is resistant to the wild-type strain. Therefore, popP1 behaves as a typical avirulence gene. We demonstrate that PopP1 protein is secreted and that secretion of this protein requires a functional type III-secretion pathway. In contrast to the structural genes for other type III-secreted proteins identified in $R$. solanacearum, transcription of the popP1 gene is not coregulated with transcription of $h r p$ genes but is constitutive.
\end{abstract}

Additional keywords: Arabidopsis thaliana, HR, type III secretion pathway, virulence, YopP

Type III secretions systems (TTSS) have a key role in the control of the interactions between pathogenic bacteria and their hosts (Cornelis and Van Gijsegem 2000; Galan and Collmer 1999; Hueck 1998). In human and animal pathogens, TTSS act to deliver bacterial proteins into the host cell cytoplasm where they express antihost functions, therefore reorienting host cell physiology to favor successful multiplication of the pathogen in host tissues.

In plant-pathogenic bacteria, TTSS are encoded by hrp genes which are found in all the major groups of gram-nega-

Corresponding author: C. Boucher; Telephone: (33) 5612854 16; Fax: (33) 5612850 61; E-mail: boucher@toulouse.inra.fr

This article is in the public domain and not copyrightable. It may be freely reprinted with customary crediting of the source. The American Phytopathological Society, 2002. tive plant-pathogenic bacteria except Agrobacterium. Indirect evidence indicates that, similarly to TTSS from mammal pathogens, the Hrp secretion machinery acts to deliver effector proteins into plant cells (Staskawicz et al. 2001). This hypothesis recently was confirmed on Xanthomonas and Pseudomonas spp. (Lahaye et al. 2002; Casper-Lindley et al. 2002). Among plant pathogens, the majority of known type III secreted proteins are Avr proteins. These proteins are host specificity factors that trigger defense mechanisms in plants harboring a matching resistance gene (Keen 1990). Type III effectors from plant pathogens, such as the DspA/E protein of Erwinia amylovora, also act as pathogenicity determinants (Bogdanove et al. 1998; Gaudriault et al. 1997). Although the functions of most of these pathogenicity factors are still mostly unknown, they are hypothesized to act by preventing the initiation of plant defense reactions or by promoting the release of nutrients from the plant cell into the apoplasm, therefore allowing active bacterial multiplication.

Avirulence functions and pathogenicity functions are not mutually exclusive and an increasing number of Avr proteins are known to act as effectors that increase the severity of symptoms when the bacterium infects sensitive plants that are devoid of a matching resistance gene (White et al. 2000).

During our analysis of the complete genome sequence of Ralstonia solanacearum, we identified several genes that code for proteins homologous to Avr proteins previously identified in other plant-pathogenic bacteria (Salanoubat et al. 2002). This situation was rather unexpected because, contrary to the situation found with most other plant-pathogenic bacteria, no gene-for-gene interaction had ever been reported for $R$. solanacearum. Only one avirulence gene, named avrA, had previously been identified in this bacterium but, unlike canonical $a v r$ genes, $a v r A$ determines host specificity at the plant species level rather than at the genotype-specific level within a particular plant species (Carney and Denny 1990).

Here we address the question of whether the $R$. solanacearum PopP1 protein, which shares homology to the YopP/YopJ pathogenicity factors from human pathogen Yersinia (Orth 2002; Orth et al. 2000) and with members of the AvrBsT family of $a v r$ genes from plant-pathogenic bacteria (Lahaye and Bonas 2001), behaves as a host-specificity determinant or as a pathogenicity TTSS effector protein. In addition, we investigate the roles of several genes flanking popP1, which were probably simultaneously acquired through horizontal gene transfer, in pathogenicity. 


\section{RESULTS}

Genetic organization of the alternative codon usage region that encodes PopP1, a new member of the YopJ/AvrRxv family.

The gene locus originally defined as RS05177 in the annotation of the complete genome sequence of $R$. solanacearum strain GMI1000 is located on the bacterial chromosome and spans 11,028 bp from position 864,361 to 875,388 .

With a base composition of $57 \% \mathrm{G}+\mathrm{C}$, this region differs significantly from the average value of $68 \%$ established for the complete genome (Fig. 1A). In addition, genes identified in this region have a codon usage that significantly differs from

Kb

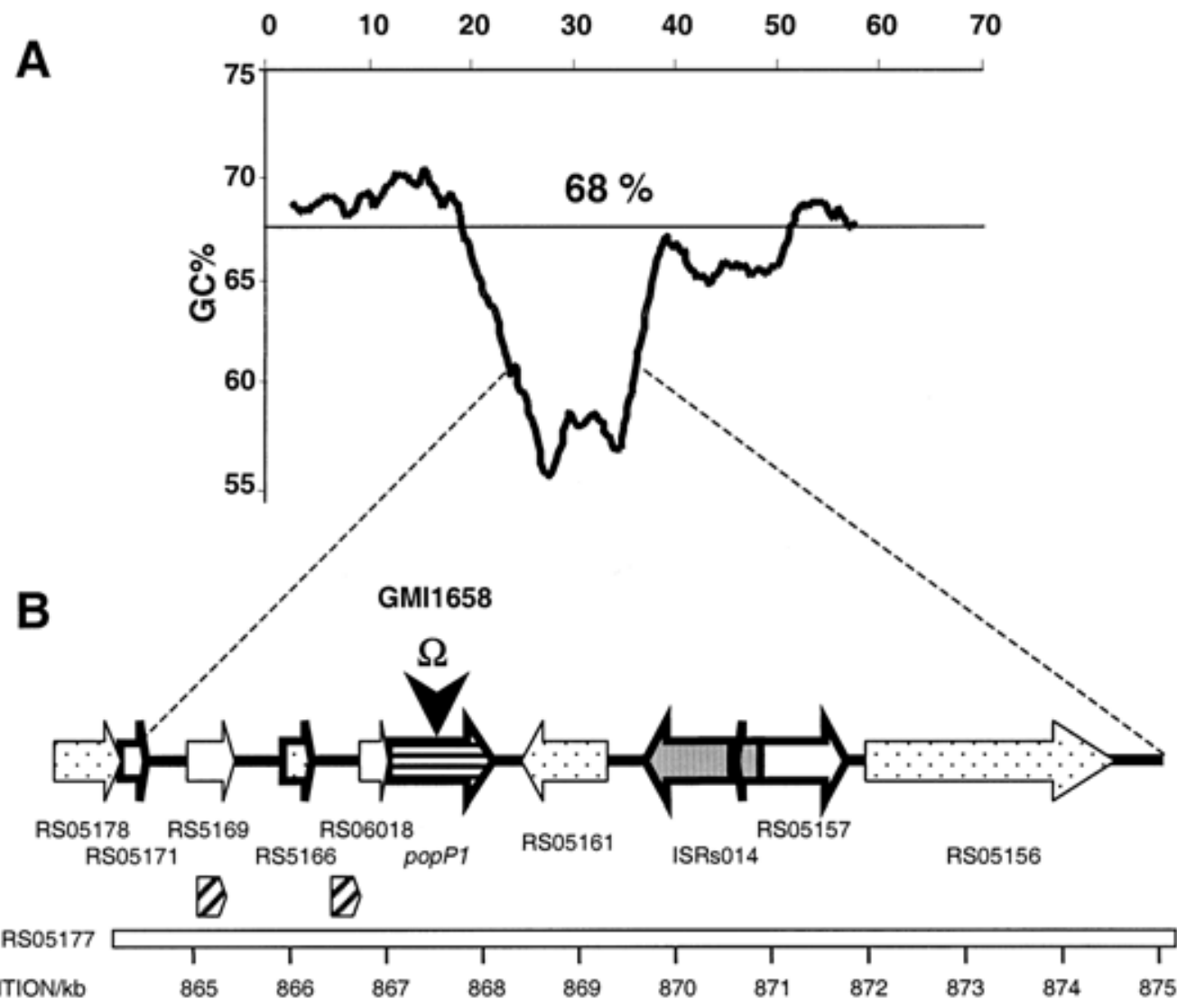

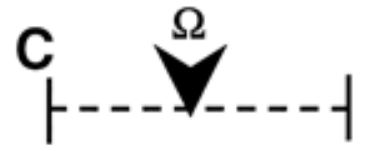

GMI1693

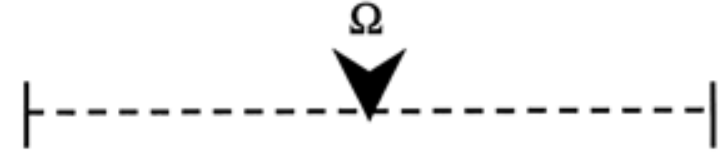

GMI1694
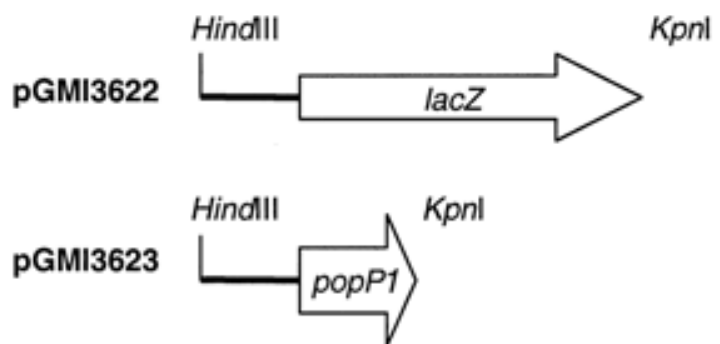

Fig. 1. Genetic organization of alternative codon usage region (ACUR) RS05177. A, Variation of G+C\% (window size: 5,000 bp, window step 250) along the ACUR and flanking regions is shown together with $\mathbf{B}$, its genetic organization. Big arrows represent the predicted protein coding genes, arrows with a thick border correspond to proteins that have partial or global homology with other proteins encoded in the genome of strain GMI1000. Open arrows correspond to proteins with no homology to known proteins, arrows filled with dots to proteins having partial homology with other proteins, gray arrows correspond to the two open reading frames coding for the transposase of insertion sequence ISRso14, and a horizontally hatched arrow represents the structural gene for the PopP1 protein. The two 280-bp DNA direct repeats present in the ACUR are shown as headless diagonally hatched arrows below the open reading frame arrows. The scale shows the position on the $R$. solanacearum strain GMI1000 chromosome. C, Several constructions used in this work, including deletion mutants GMI1695 and GMI1696 (dashed lines), insertion sites for the $\Omega$ interposon (arrow heads), and plasmid inserts (solid lines and open arrows). The narrow white arrows represent the coding sequence for $\beta$-galactosidase. 
the general codon usage of the organism and were thus classified as an alternative codon usage region (ACUR) (Salanoubat et al. 2002). It harbors one of the four copies of the insertion sequence ISRso14 identified in the complete genome and two 280-bp-long nearly perfect DNA direct repeats at positions 865,112 to 865,391 and 866,636 to 866,916 (Fig. 1B). At least four additional copies of this repeat also are present elsewhere in the genome. Moreover, two stretches of DNA located within ISRso14 and spanning positions 868,630 to 869,036 and 869,239 to 869,661 have 87 and $83 \%$ homology, respectively, at the DNA level with two internal fragments of IS407 first identified in Burkholderia cepacia (Wood et al. 1991).

In addition to the two open reading frames (ORF) coding for the ISRso14 transposase, eight additional proteins encoding genes have been predicted in this region. Two of these genes, (RS05169 and RS06018) code for proteins which have no homology with any known proteins, whereas two others (RS05171 and RS05157) code for proteins which have partial homology only with other $R$. solanacearum hypothetical proteins.

Accession RS05161 codes for a protein of unknown function shared with Agrobacterium spp., various Rhizobium spp., and Brucella melitensis. This protein and its corresponding homologues all are predicted to harbor a potential esterase/lipase/thioesterase active site as defined in Prosite (PS0187).

Accession RS05156 encodes a protein which shares homology with a domain of 220 amino acid (aa) residues present in the secA-related protein from Vibrio cholerae (accession TrEMBL: Q9KLW3). In addition, the C-terminus of this protein harbors the Sec-C motif present in the SecA protein (Interpro IPR004027). This domain is predicted to chelate zinc and potentially to bind nucleic acids. RS05156 also is predicted to harbor a P-loop ATP/GTP binding motif (PR00017) at position 86-93.

The two remaining proteins share homology with proteins reported or suspected to play a role in the control of plant-bacterial interactions.

RS05166 has 54\% identity and $72 \%$ similarity over 33 aa located at the N-terminus of the protein PthG (accession AAC24862) encoded on the pPATH plasmid from Erwinia herbicola pv. gypsophilae (Ezra et al. 2000). PthG acts to increase aggressiveness of E. herbicola pv. gypsophilae toward gypsophilum and as an avirulence protein in beet. RS05166

\section{Plant pathogens and Plant symbiont}

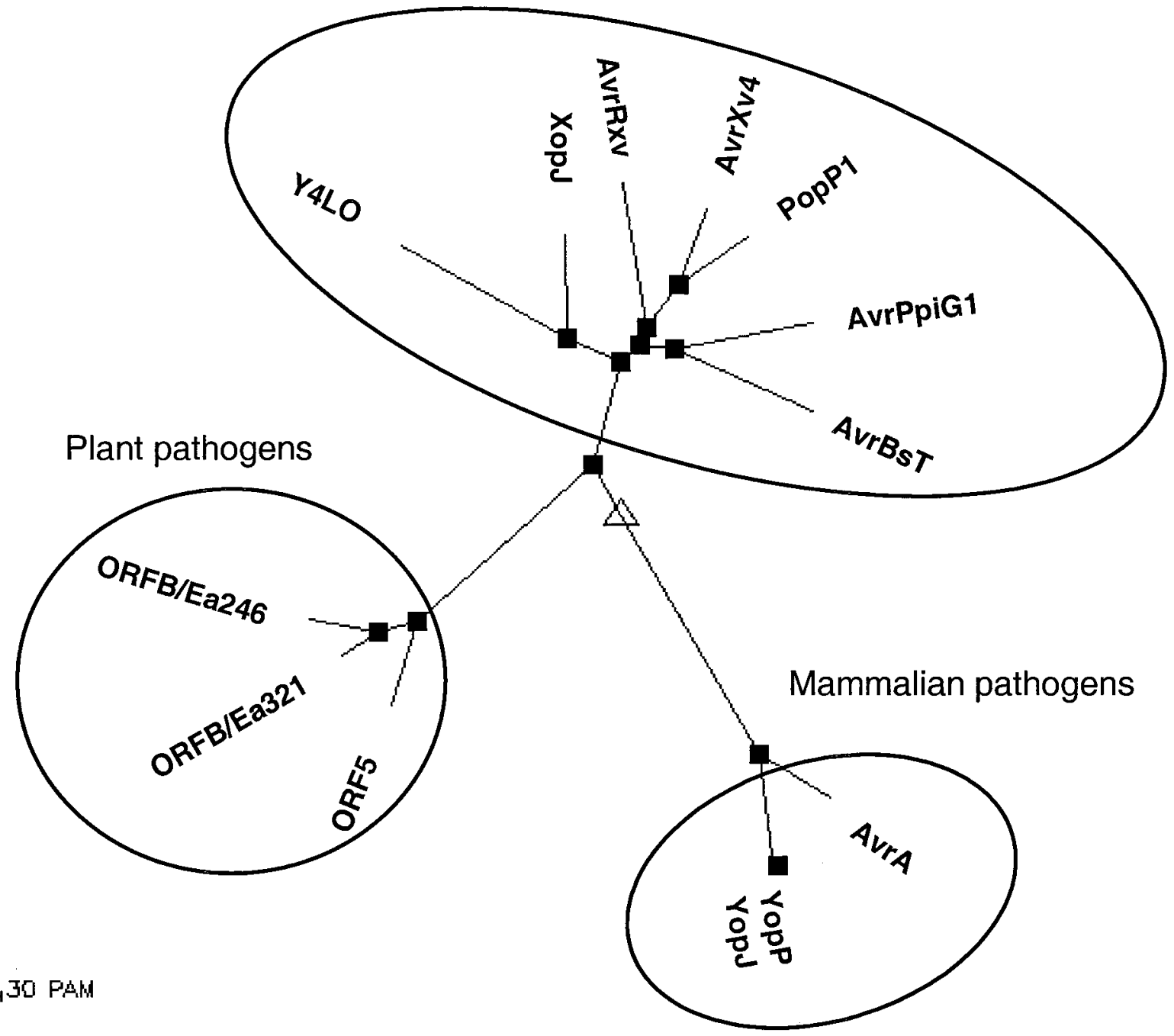

Fig. 2. Phylogenetic tree, showing the relationships between proteins from the YopJ/AvrRxv protein family. This tree was generated from a protein alignment generated by Multalin. Accession numbers for the proteins are: Yersinia pseudotuberculosis YopJ, P31498; Y. enterocolitica YopP, NP-052382; Salmonella enterica AvrA, AAB83970; Xanthomonas axonopodis (campestris) AvrRxv, Q08678; AvrBsT, AAD39255; XopJ, AAK72486; AvrXv4, AAG39033; Pseudomonas syringae AvrPpiG1, CAC16700; Orf5, AAF71492; Rhizobium sp. Y4LO, NP-443964; Erwinia amylovora OrfB Ea246, AAF63400; and OrfB Ea321, AAF63397. 
has a homologue (RS04524) in strain GMI1000. The N-terminus of RS05166 also shares homology with the N-terminus of RS05218 from the GMI1000 proteome.

Finally, RS05162 encodes a protein subsequently referred to as PopP1, which is a member of the YopJ/P/AvrRxv family of effector proteins translocated through type III secretion pathways (Lahaye and Bonas 2001; Orth et al. 2000). These effectors are shared among mammalian and plant pathogens and have been proposed to act as cysteine proteases because they all harbor three specific amino acids at certain positions that are characteristic of the active site of such enzymes (Orth et al. 2000). A multiple alignment of the members of this family shows that, although these proteins are relatively well conserved in their central domain, they are significantly divergent both at the $\mathrm{N}$ and $\mathrm{C}$ termini (data not shown).

The popPl gene is predicted to encode a $41-\mathrm{kDa}$ protein with a isoelectric point of 7.87 and harbors the conserved triad of amino acids characteristic for cysteine proteases (Orth et al. 2000). Analysis of the relationship between PopP1 and other related proteins performed using alignments generated by Multalin (Corpet 1988) revealed that the PopP1 protein is closely related to the avirulence proteins AvrRxv, AvrBsT, AvrXv4, and XopJ from Xanthomonas spp., to the AvrPpiG1 protein from Pseudomonas syringae pv. Pisi, and to the Y4LO protein from Rhizobium sp. NGR234 (accession NP-443964). On the other hand, although PopP1 clearly shows weak homology to members of the family found among human pathogens (YopP, YopJ, and AvrA) and from a third group consisting of three other avirulence proteins accessions (AAF63400, AAF63397, and AAF71492), identified in the plant pathogens E. amylovora, and $\mathrm{P}$. syringae pv. syringae, respectively, it is nevertheless evolutionarily much more distant to the latter groups (Fig. 2).

\section{PopP1 encodes an Avr protein which modulates} aggressiveness of the bacterium toward host plants.

In order to investigate whether genes located within ACUR RS05177 are involved in the control of plant-bacteria interac- tions, three mutants were constructed. The popPl-deficient mutant GMI1658 was generated by insertion of the $\Omega$ interposon at the BamHI restriction site of the gene. The two deletion mutants GMI1695 and GMI1696 were constructed by replacing the right and left ends of the popPl-flanking region of the ACUR by the $\Omega$ interposon. Therefore, mutant GMI1696, in addition to lacking one copy of ISRso14, was deficient for the functions encoded by RS05161, RS05157, and RS05156; and mutant GMI1695 was deficient for RS05166, RS05169, RS05171, and RS05178 but still retained RS06018 (Fig. 1C).

These mutants were compared with the wild-type strain for their ability to induce a hypersensitive response (HR) on tobacco and to cause wilting on tomato and Arabidopsis thaliana ecotype Col-5. Following infiltration into tobacco leaves, none of the three mutants were affected in the HR-inducing ability (data not shown). The evolution of the average disease index from three independent pathogenicity assays performed on batches ranging from 10 to 46 A. thaliana plants is shown in Figure 3 . The distribution of the wilting index in the population is not normal; therefore, standard deviations are inappropriate, and a nonparametric statistical test is necessary to analyze these results. The results of eight independent pathogenicity tests on A. thaliana ecotype Col-5 and Lycopersicon esculentum cv. Supermamande using the $\chi^{2}$ test, where the plants are noted simply as healthy or diseased, is summarized in Table 1. Apparition of the first symptoms and development of the disease reproducibly occurred 1 or 2 days earlier among plants that were inoculated with the popPl mutant compared with plants inoculated with the wild-type parent, but the time required for appearance of the first symptoms differed slightly from one experiment to another, probably depending on variation on the plant growth stage at inoculation time between the different batches of plants used for the different assays and the bacterial inoculum density used. In contrast, no clear phenotypic trait was observed following inoculation of the two deletion mutants GMI1695 and GMI1696 on tomato plants or on A. thaliana ecotype Col-5 (data not shown).

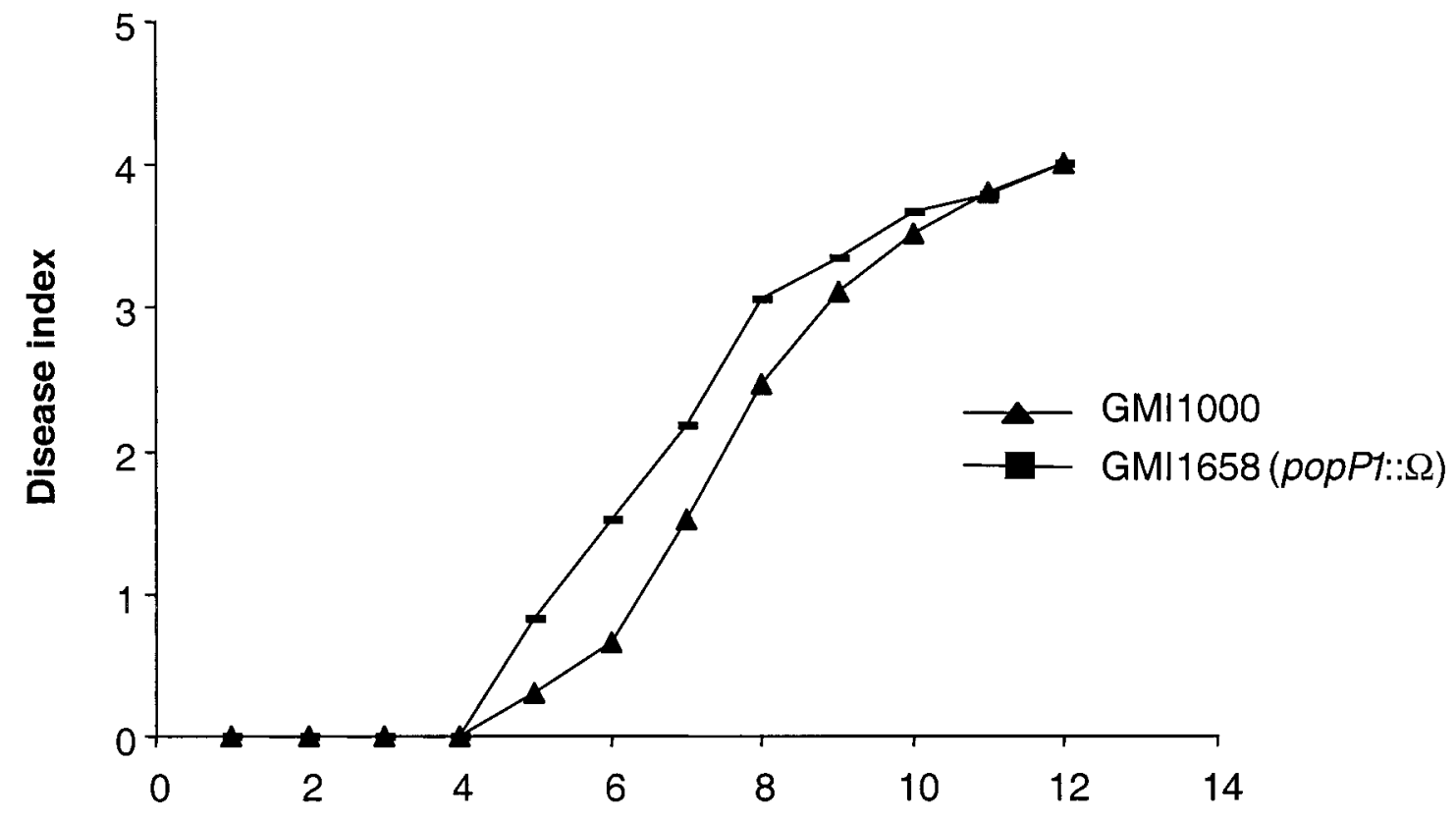

\section{Days post-inoculation}

Fig. 3. Aggressiveness of the popP1 deficient mutant on Arabidopsis thaliana Col-5 evolution of the average disease index over time of plant inoculated with the wild type strain GMI1000 (bars) and with the popP1 mutant GMI1658 (triangles). Values are averages of three independent assays. 
Different lines of both Arabidopsis (Deslandes et al. 1998) and Petunia (Arlat et al. 1994) show variation in their responses to inoculation with strain GMI1000. The PopP1 protein shares homology with a class of avirulence proteins; therefore, we compared the ability of the wild-type strain and of its popPl mutant derivative to cause disease on the resistant line of Petunia St40 and on the resistant ecotype Nd-1 of Arabidopsis. The popPl mutant became virulent on line St40 and avirulence was restored when the mutant was complemented with plasmid pGMI3623, which harbors a functional popPl gene (Fig. 4A). Therefore, the popP1 gene behaves like a classical avirulence gene. This was further confirmed when plasmid pGMI3623 was introduced into strain $\mathrm{Rd} 15$ of $R$. solanacearum, a strain virulent for Petunia St40 (Fig. 4B). The transconjugants thus obtained had lost their ability to wilt Petunia St40. On the other hand, no phenotypic difference was observed between the wild-type strain and its popP1 mutant derivative when the bacteria were tested for virulence on Arabidopsis ecotype $\mathrm{Nd}-1$, which remained resistant to both strains (data not shown).

\section{PopP1 is secreted via the TTSS of $R$. solanacearum.}

The data presented above strongly suggest that, like other members of the YopJ/AvrRxv protein family, PopP1 might be translocated through the TTSS encoded by hrp genes. In order to test this hypothesis, Western blot analyses were conducted to compare the partitioning of PopP1 between bacterial cells and concentrated culture supernatants in the wild-type strain GMI1000 and in the two hrp mutants GMI1402 ( $h r p V$ ) and GMI1410 ( $h r p Y$ ) after growth in minimal medium which is known to induce TTSS. This was done using a polyclonal antiserum which we raised against purified PopP1 protein. These experiments established that the PopP1 protein is present in the culture medium from the wild-type strain but not from the hrp mutants (Fig. 5). On the other hand, a clear band was detected in cell lysates prepared from the wild-type strain and its hrp derivatives, demonstrating that the PopP1 protein actually is secreted through the TTSS. As a control, we found that this band was absent from the culture supernatant and the cell lysate of the popP1 mutant, although a weak (nonspecific) band with a similar electrophoretic mobility still was observed in the cell lysate of the mutant. The popP1 mutant was not affected in its ability to secrete other type III-secreted proteins such as PopA (Fig. 5B). In additional experiments using $\beta$-galactosidase-producing

Table 1. Comparison of the aggressiveness of a popP1 mutant strain of Ralstonia solanacearum with its wild-type progenitor in different host plants

\begin{tabular}{lccc}
\hline Test no. & $\begin{array}{c}\text { Plant line } \\
\text { (inoculum density) }^{\mathbf{a}}\end{array}$ & DPI $^{\mathbf{b}}$ & $\begin{array}{c}\text { No. diseased/ } \\
\text { no. inoculated plants }\end{array}$ \\
\hline 1 & Col-0 (high) & 8 & $23 / 35^{* * *}$ \\
2 & Col-0 (high) & 6 & $20 / 46^{* * *}$ \\
3 & Sm (high) & 3 & $15 / 48^{* *}$ \\
4 & Sm (high) & 3 & $12 / 50^{*}$ \\
5 & Sm (high) & 3 & $10 / 40^{\text {d }}$ \\
6 & Sm (medium) & 4 & $27 / 48^{* * *}$ \\
7 & Sm (medium) & 4 & $70 / 80^{* * *}$ \\
8 & Sm (low) & 4 & $39 / 80^{\mathrm{d}}$ \\
\hline
\end{tabular}

${ }^{\text {a }}$ Arabidopsis (tests 1-2) ecotypes or tomato cv. Supermarmande (tests 3-8) per milliliter inoculated with differing densities of bacterial cultures of GMI1000popP1:: $\Omega$ (high $=108 / \mathrm{ml}$., medium $=107 / \mathrm{ml}$, low $=106 / \mathrm{ml}$ )

${ }^{\mathrm{b}}$ DPI $=$ days post inoculation. Notation of symptoms on the day showing the clearest difference between GMI1000popP1:: $\Omega$ and GMI1000 wildtype inoculations.

c The number of diseased plants was counted and compared, by the $\chi^{2}$ test, to a similar number of plants inoculated with the wild-type strain (data for the latter is not shown). The level of significance is indicated by asterisks; $*=P<0.05, * *=P<0.01$, and $* * *=P<0.001$.

${ }^{\mathrm{d}}$ The $\chi^{2}$ test could not be applied because none of the plants in the wildtype control had wilted at this time point. strains, we ruled out the possibility that the presence of PopP1 in the culture supernatant could be due to cell lysis, because no $\beta$ galactosidase was detected in the supernatants from bacterial cultures (data not shown).

\section{popP1 does not belong to the hrpB regulon.}

So far, three effector proteins (PopA, PopB, and PopC) which are secreted via $R$. solanacearum TTSS have been identified. All three are encoded within a single operon which belongs to the $h r p B$ regulon (Guéneron et al. 2000). Genes belonging to this regulon are not expressed when the bacterium is grown in rich culture medium and require the presence of the transcriptional activator $\mathrm{HrpB}$ to be transcribed during growth in minimal medium. A consensus motif (TTCGN 16 TTCG) recently has been identified in the promoter of $h r p B$-regulated genes (S. Cunnac, S. Genin, and C. Boucher, unpublished data). Such a motif is present 203 to 178 bp upstream of the popPl start codon, suggesting that this gene might belong to the $h r p B$ regulon. In order to test this hypothesis, a transcriptional gene fusion was generated between the popPl promoter and a promoterless lacZ reporter gene. This construction was cloned in the wide host range vector pLAFR6, thus generating plasmid pGMI3622, which then was introduced into the wild-type strain GMI1000. The resulting transformant was tested for $\beta$-galactosidase activity during growth in rich and minimum media. In contrast to a control construction where the reporter gene was driven by the typically $h r p B$-regulated promoter of $h r p Q$, growth in rich medium of the strain carrying the ppopP $1: \because$ lac $Z$ did not affect expression of $\beta$ galactosidase activity (Fig. 6A). In addition, expression of the ppopP1::lacZ fusion was not affected in minimal medium when plasmid pGMI3622 was introduced into an $h r p B$-deficient mutant (Fig. 6B). This clearly demonstrates that transcription of the popPl gene does not require a functional $\mathrm{HrpB}$ protein to be present and thus proves that this gene does not belong to the $h r p B$ regulon.

\section{popP1 transcription is not dependent on regulatory genes acting upstream of hrpB in the regulatory cascade.}

We previously identified a set of regulatory genes acting upstream of $h r p B$ (Brito et al. 1999, 2002; Marenda et al. 1998). Among these, the $p r h A$ gene, which acts as a sensor for contact of the bacterium with plant cells (Aldon et al. 2000) and $h r p G$, which acts immediately upstream of $h r p B$, are probably involved in the control of $h r p$-independent pathogenicity functions (Vasse et al. 2000). Therefore, we investigated whether transcription of the popPl gene could be placed under the control of one of these two genes. We first introduced plasmid pGMI3622 into the $h r p G$ mutant GMI1578 and compared the level of $\beta$-galactosidase activity produced during growth in minimal medium with that produced under the same conditions when the plasmid was present in the wild-type strain GMI1000. No significant effect of the $h r p G$ mutation was observed in this experiment (Fig. 7).

Similarly, a $p r h A$ mutation had no effect on the activity of the $p o p P 1$ promoter when bacteria were grown in co-culture with $A$. thaliana plant cells (data not shown).

Therefore, the popPl gene appears to be expressed constitutively under all of the conditions that we tested and it is very likely that none of the transcriptional activators of the hrp regulation cascade as defined by Brito and associates (2002) are required for its expression.

\section{DISCUSSION}

\section{Like other plant pathogens, $R$. solanacearum harbors avirulence genes.}

We show that the PopP1 protein in the strain GMI1000 of $R$. solanacearum is a TTSS-dependent effector which acts as 
an avirulence factor toward Petunia St40. In contrast to the structural genes for the PopA, PopB, and PopC TTSS-dependent effectors previously characterized in this bacterium, the popPl gene is not located in the vicinity of the hrp gene cluster on the megaplasmid but on the bacterial chromosome. This validates our previous prediction made from genome analysis (Salanoubat et al. 2002) that, in $R$. solanacearum, both replicons are involved in the production of TTSS-dependent bacterial effectors.

We show that popPl is a canonical avirulence gene because it controls host specificity in a plant genotype-dependent pattern, acting as an avirulence gene toward Petunia St 40 but not toward sensitive Petunia Tr66 (Arlat et al. 1994) or the resistant ecotype Nd-1 of $A$. thaliana (Deslandes et al. 2002).

In contrast, the $a v r A$ avirulence gene previously identified in $R$. solanacearum strain AW1 showed no differential response among cultivars of Nicotiana tabacum (Carney and Denny 1990). We hereby present the first clear evidence that mechanisms which govern host-specificity in Pseudomonas and Xanthomonas leaf pathogens may be shared in rhizospheric Ralstonia. As a corollary, we might expect that major dominant resistance genes to $R$. solanacearum acting in a "gene-for-gene" manner probably are present in plants, although they had not yet been clearly identified among crop plants. Existence of a novel recessive resistance gene to $R$. solanacearum has also been exemplified recently with the cloning of a resistance gene from A. thaliana for which the matching avirulence gene also remains to be identified (Deslandes et al. 2002).

\section{Does PopP1 act as a weak avirulence protein} in some cases?

When inoculated on tomato and on the compatible ecotype Col-5 of A. thaliana, the popP1-deficient mutant was found to be more aggressive than the wild-type strain. This could be explained if $p o p P l$ is recognized as a weak avirulence gene in

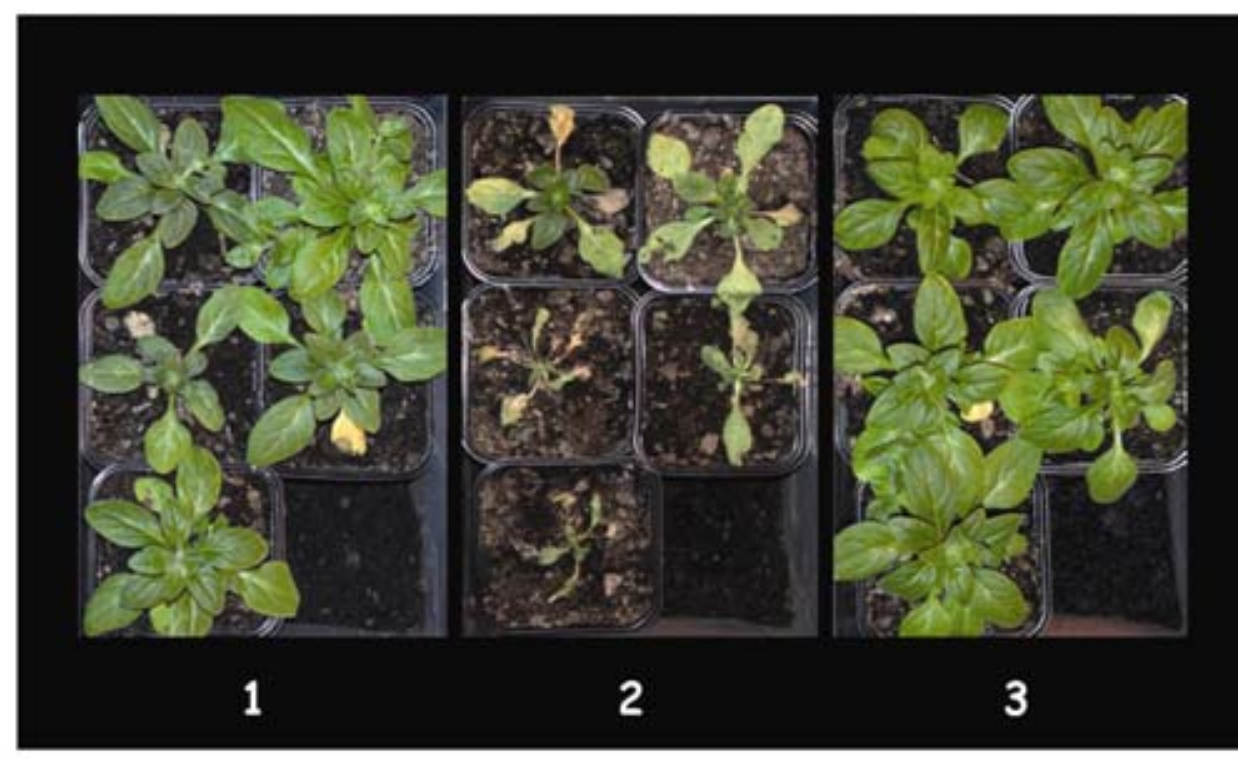

A

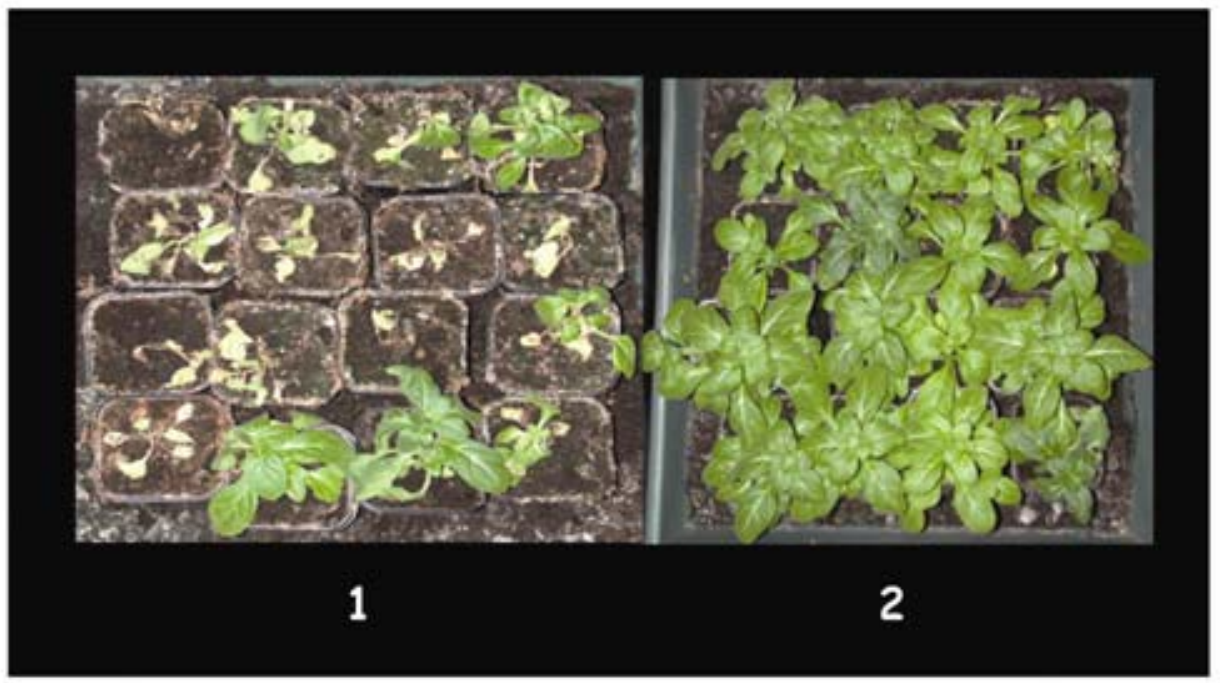

B

Fig. 4. Avirulence function of popP1. A, Behavior of petunia St40 inoculated with the wild-type strain GMI1000 (1), with the popP1 mutant GMI1658 (2), and with this mutant complemented with plasmid pGMI3623 which carries a functional popP1 gene (3). B, Virulence of strain Rd15 (1) and of a transconjugant carrying plasmid pGMI3623 (2) on petunia St40. Pictures were taken 15 days post inoculation. 
these plants, a notion which is in agreement with the discovery of more complex polygenic resistance to bacterial wilt in tomato (Mangin et al. 1999; Wang et al. 2000).

\section{Could PopP1 be a pathogenicity effector?}

The discovery of popPl in R. solanacearum extends the distribution of proteins of the YopJ/AvrRxv family to the group of $\beta$-proteobacteria. Members of this family previously had been identified in the $\alpha$ - (Rhizobium) and $\gamma$ - (Salmonella, Yersinia, Erwinia, Xanthomonas) subdivisions of proteobacteria. Among these bacteria, members of YopJ/AvrRxv family are found specifically in bacteria that have a TTSS and that do interact with plant or animal cells. Considering the wide conservation of this gene family among bacterial pathogens (and the bacterial symbiont Rhizobium), it seems likely that these proteins may play a crucial role in host colonization. This actually has been demonstrated for YopP in Yersinia enterocolitica (Denecker et al. 2001). Our data establish that popPl is not essential for pathogenicity of strain GMI1000 on tomato or Arabidopsis spp. However, no definitive conclusion can be drawn concerning the contribution of PopP1 to pathogenicity functions because a second ORF (RS04882) potentially encoding a member of this protein family has been identified in the genome of strain GMI1000 (Salanoubat et al. 2002). Further experiments, including the generation of a mutant inactivat- ing both popPl and the gene coding for its homologous protein PopP2, are required before the status of the PopP1 protein in the control of plant-bacteria interactions can be definitively established. Similar double and triple mutants also are needed before a definitive conclusion can be drawn concerning RS05166, for which two homologous proteins are encoded in the genome of strain GMI1000 (Salanoubat et al. 2002).

\section{Two classes of hrp effectors can be defined based on regulation patterns.}

We show that the popPl gene is expressed in $R$. solanacearum independently of the transcriptional activator HrpB. This is reminiscent of the situation found for avrRxv in Xanthomonas campestris, where this gene is expressed constitutively, independently of the transcriptional activator HrpX and of integrity of the PIP-box present upstream of the gene (Ciesiolka et al. 1999). The constitutive expression of popPl contrasts with the status of the popABC operon which belongs to the hrp regulon (Guéneron et al. 2000). Accordingly, based on the regulatory pattern of the corresponding structural genes, at least two classes of type III effectors can be distinguished in $R$. solanacearum. Whether the constitutive expression of a subset of effectors might have a biological significance, for example in the timing of production or secretion of different effector proteins during the infection process, remains to be established.
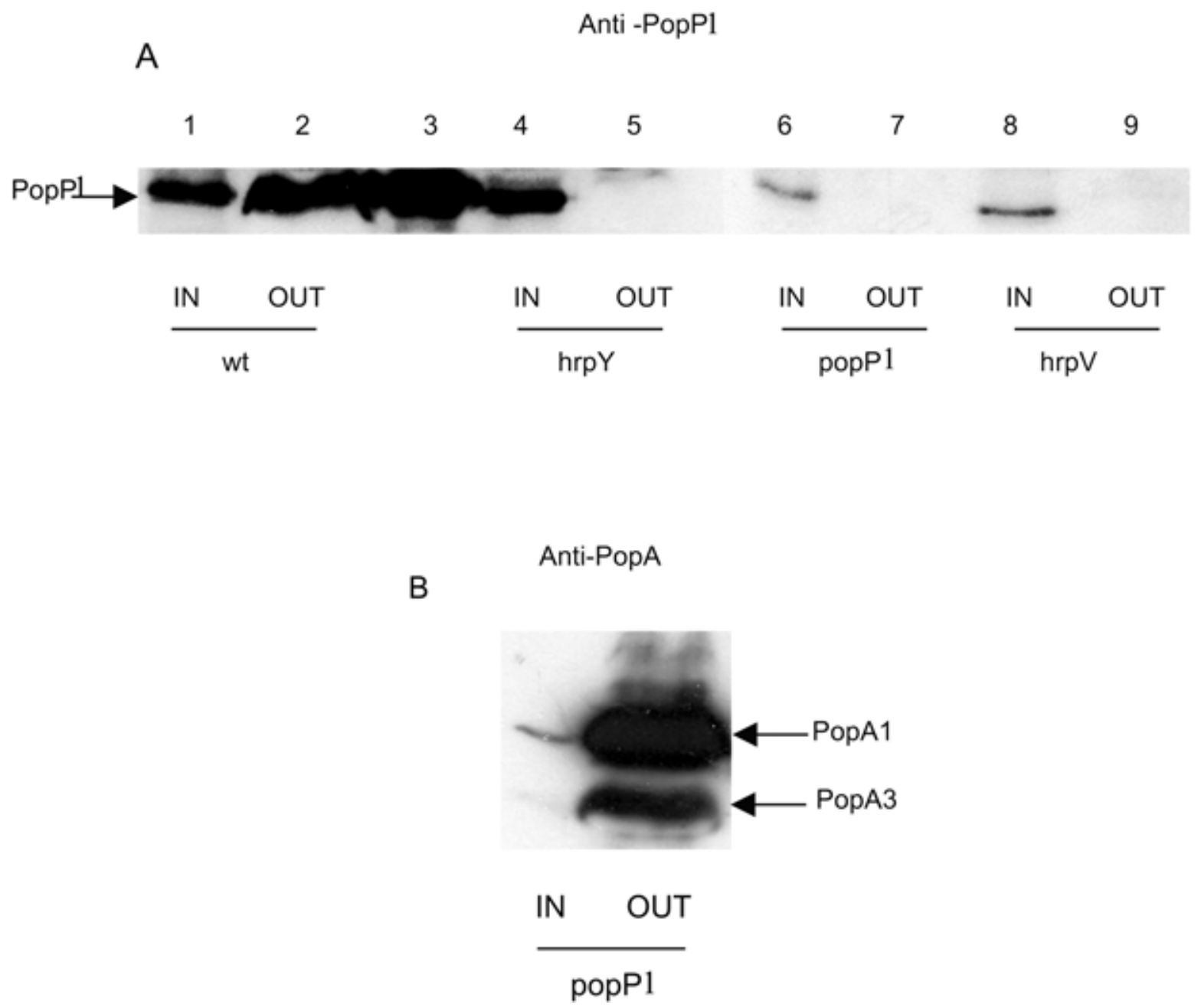

Fig. 5. Hrp-dependent secretion of the PopP1 protein. Western blots of concentrated supernatant preparations (CSPs) (lanes 2, 5, 7, 9) and of cell free lysates (lanes 1, 4, 6, 8 ) from the wild-type strain GMI1000 (wt), the $h r p V$ mutant GMI1492 ( $h r p V$ ), the hrpY mutant GMI1410 (hrpY), and the popP1 mutant GMI1658 (popP1) using antibodies raised against the A, PopP1 and $\mathbf{B}$, PopA proteins. Lane 3 in $\mathbf{A}$ is a control for the electrophoretic mobility of purified PopP1 protein. 
ACUR RS05177 might be part

of a larger pathogenicity island.

ACUR RS05177 displays several features characteristic of a pathogenicity island (PAI) (Hacker et al. 1997): (i) it has a base composition that is shifted $10 \%$ from the average $\mathrm{G}+\mathrm{C} \%$ of the genome; ii) in addition to popP1, two other genes (RS05166, a homologue of the pthG gene of E. herbicola [Ezra et al. 2000] and RS05156, a homologue of a V. cholerae protein [Heidelberg et al. 2000]) are likely to play a role in plant-bacteria interactions; and (iii) an insertion sequence is present in this element. However, ACUR RS05177 might itself be part of a larger PAI extending $75 \mathrm{~kb}$ downstream of popP1 and bordered by the $s s r A$ gene which codes for a bacterial tmRNA (previously known as 10Sa RNA in Escherichia coli) (Komine et al. 1994). In Dichelobacter nodosus and V. cholerae, the ssrA gene is thought to be a target site for horizontal transfer of virulence genes, because virulence or virulence-related gene clusters are found physically linked to this locus (Cheetham and Katz 1995; Hacker et al. 1997; Kovach et al. 1996). Extension of the PAI down to the ssrA locus also is justified by the presence of two additional ACURs, several bacteriophage remnants, and two additional insertion sequences in this region. It also would explain why the borders of ACUR RS05177 do not correspond to the location of the $\mathrm{G}+\mathrm{C} \%$ shift around the ACUR (Fig. 1A).

\section{MATERIALS AND METHODS}

Molecular biology techniques.

Standard methods were used (Ausubel et al. 1990) unless otherwise stated. Genomic DNA was extracted from $R$. solanacearum strains as described by Arlat and associates (1992). Polymerase chain reaction (PCR) amplifications were done using the Expand Long Template PCR System (Roche Molecular Systems, Inc. Branchburg, NJ, U.S.A.).

Bacterial strains, plasmids, and growth conditions.

Bacterial strains and plasmids used in this study are listed in Table 2. E. coli strains were grown in Luria-Bertani medium
(Sambrook et al. 1989) at $37^{\circ} \mathrm{C}$. $R$. solanacearum strains were grown at $28^{\circ} \mathrm{C}$ on either $\mathrm{B}$ medium or minimal medium (Boucher et al. 1985) supplemented with $20 \mathrm{mM}$ glutamate (MMG). When indicated, MMG was supplemented with Congo red $\left(100 \mu \mathrm{g} \mathrm{ml}^{-1}\right)$. Antibiotics were used at the following concentrations: tetracyclin, $10 \mathrm{mg} \mathrm{l}^{-1}$; kanamycin, $50 \mathrm{mg} \mathrm{l}^{-1}$ ampicillin, $50 \mathrm{mg} \mathrm{l}^{-1}$; spectinomycin $(\mathrm{Sp}), 50 \mathrm{mg} \mathrm{l}^{-1}$; and streptomycin $(\mathrm{Sm}), 50 \mathrm{mg} \mathrm{l}^{-1}$.

\section{Bacterial transformation.}

Transformation of strains of $R$. solanacearum leading to homologous recombination of the incoming DNA was performed according to the method described by Boucher an associates (1985). Plasmids were introduced into $R$. solanacearum strains by electroporation $(2.5 \mathrm{kV}, 200 \mathrm{ohms}, 25 \mu \mathrm{Fd}, 0.2-\mathrm{cm}$ cuvette gap).

\section{Sequence analysis.}

Homology searches and PROSITE pattern searches were performed using the NCBI Blast server.

\section{Construction of bacterial strains carrying mutations in and around popP1.}

The popPl gene was disrupted by insertion of the $\Omega$ interposon. A 1,655-bp DNA fragment containing the popPl gene was amplified by PCR using strain GMI1000 genomic DNA as template and primers A1 (5'-AAGCTTAAGAGTTGCGGTGGC- $3^{\prime}$ ) and A2 (5'-TCTAGAAATGTAGAAGGAAGC- $3^{\prime}$ ). The underlined sequences correspond to restriction sites: $H$ indIII in primer A1 and $X b a I$ in primer A2. After amplification, the DNA fragment was digested with HindIII and XbaI and cloned into HindIII-XbaI-digested pBluescript, generating plasmid pBluescript(popP1). This plasmid was partially digested with $B a m \mathrm{HI}$ and the digestion product was ligated with the $\Omega$ interposon purified after BamHI digestion of plasmid pHP45 $\Omega$ (Prentki and Krisch 1984). This interposon confers resistance to $\mathrm{Sp}$ and $\mathrm{Sm}$. Clones which contained a single $\Omega$ insertion in the BamHI site of popPl were selected based on restriction profile analysis. This construct then was linearized
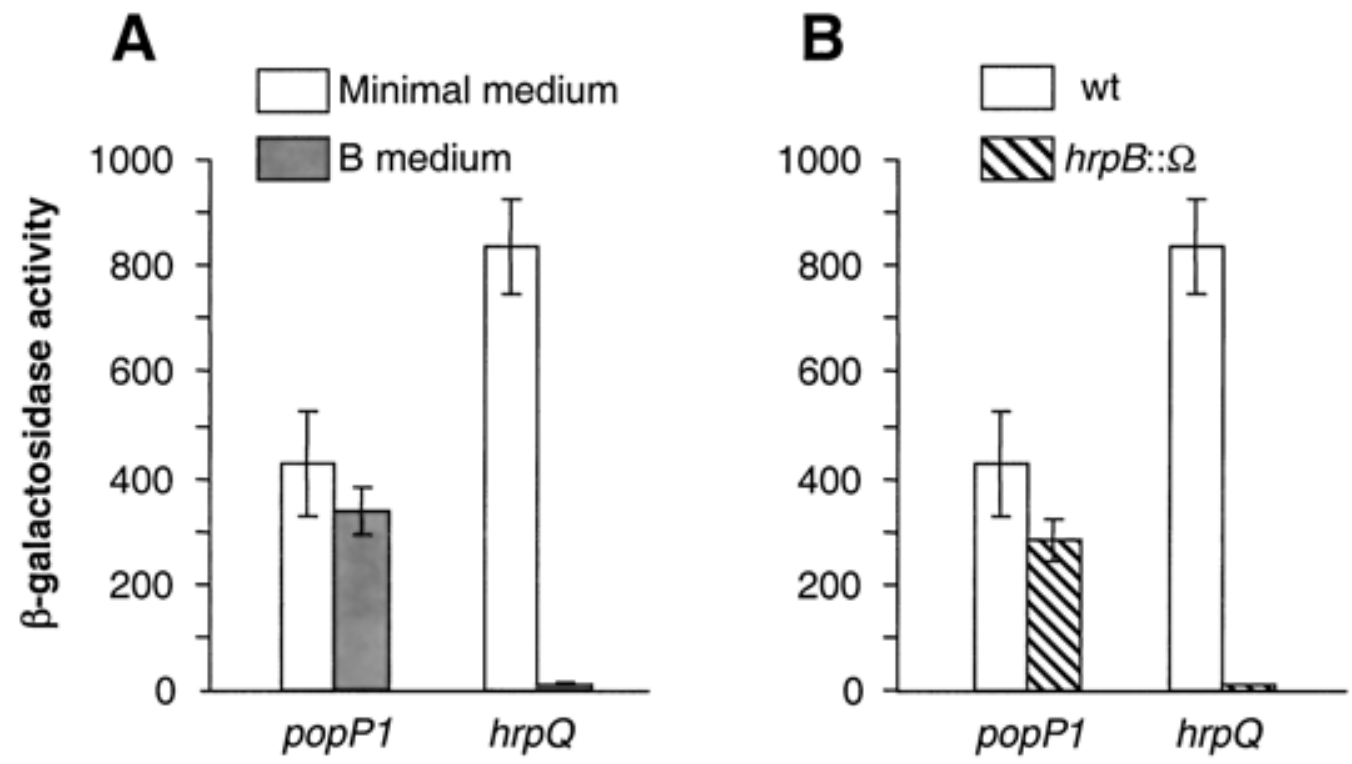

Fig. 6. The popPl gene does not belong to the $h r p B$ regulon. A, Effect of culture medium and $\mathbf{B}$, dependence of popP1 transcription on $h r p B$ ). A, Comparative $\beta$-galactosidase activity of a popP1::lacZ transcriptional fusion carried by plasmid pGMI3622 in strain GMI1000 grown in minimal medium (unfilled columns) and B medium (gray columns) or B, in minimal medium in a wild-type strain versus the hrpB-deficient mutant GMI1525 (hatched columns). The $\beta$-galactosidase activity driven by the $h r p Q$ promoter carried on plasmid pGMI1957 under similar conditions is given as a control for a gene belonging to the $h r p B$ regulon. Bars correspond to standard error. 
by digestion with $\mathrm{XbaI}$ and used to transform $R$. solanacearum strain GMI1000, selecting for Sm resistance.

In order to construct strain GMI1695, which is deleted for RS05166, RS05169, RS05171, and RS05178, a 973-bp DNA fragment spanning from position 866,236 to 867,209, upstream of the popPl start codon, was generated by PCR using GMI1000 genomic DNA as a template and primers P1-HindIII (5'-AAGCTTGCGAGGCAAAACTCT-3') and P2-XbaI (5'TCTAGACGTTGCGAGATTCCA-3'). The PCR product was digested by HindIII and $X b a I$ and cloned into the XbaI-HindIII digested pBluescript $\mathrm{SK}(-)$ vector, generating $\mathrm{pBSF}$ 1. In addition, the 815 -bp DNA fragment spanning from position 862,809 to 863,624 was amplified using primers dela-HindIII (5'-AAGCTTTAGCTTATTTTT-3') and delb-XhoI (5'CTCGAGAGATGGCTGACGCGTAAT- $3^{\prime}$ ). The PCR product was digested by XhoI and HindIII and cloned into pBSF1 digested with XhoI and HindIII, thus generating plasmid pBSF2. A HindIII-restricted $\Omega$ interposon then was cloned into the
HindIII restriction site of pBSF2, generating plasmid pBSF3. This last plasmid was linearized by $\mathrm{XbaI}$ and used to transform $R$. solanacearum GMI1000, selecting for Sm resistance.

Mutant strain GMI1696 was constructed by deletion of all the ORF located downstream of popPl in the ACUR RS05177. The 754- and 789-bp fragments spanning positions 867,802 to 868,556 and 874,886 to 875,675 , respectively, were amplified by PCR using the respective pairs of primers DSmaI, BamHI, EcoRI (5'-CCCGGGGGATCCGAATTCGTC ATCTCTGACGTAGCC-3'), and D-XbaI (5'-TCTAGAATACCGAACTGGCGAGTG- $3^{\prime}$ ) on one side and U-HindIII (5'AAGCTTATCCCTAAGGGCCATCAG-3'), U-EcoRI, BamHI, and $\operatorname{SmaI}\left(5^{\prime}\right.$-GAATTCGGATCCCCCGGGTGTTCTCCTCCACTCGCA-3') on the other side. The overlapping complementary sequences of fragment $\mathrm{D}$ and $\mathrm{U}$ were combined and the resulting 1,543-bp D-XbaI/U-HindIII fragment was amplified in a third PCR using D-XbaI and U-HindIII primers as described by Higuchi (1990). The D-XbaI/U-HindIII fragment

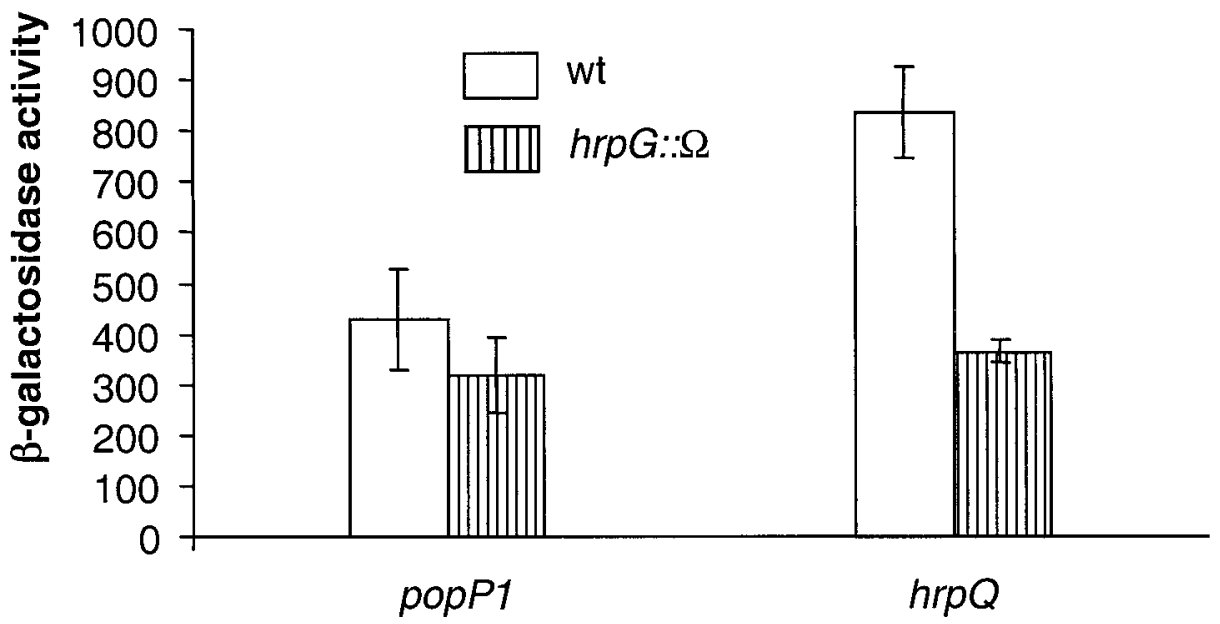

Fig. 7. Transcription of $p o p P 1$ is independent of the HrpG transcriptional activator. Comparison of $\beta$-galactosidase activity of the ppopP1::lacZ fusion carried by plasmid pGMI3622 when expressed in the wild-type strain GMI1000 (white columns) or in the hrpG mutant GMI1578 (verticals hatched columns) under inducing conditions. Activity driven by the $h r p Q$ promoter carried on plasmid pGMI1957 under similar conditions is given as a comparison with a $h r p G$ regulated gene. Bars correspond to standard error.

Table 2. Bacterial strains and plasmids

\begin{tabular}{|c|c|c|}
\hline Strain/plasmid & Relevant characteristics $^{\mathrm{a}}$ & Reference/source \\
\hline \multicolumn{3}{|l|}{ Bacteria } \\
\hline \multicolumn{3}{|l|}{ Escherichia coli } \\
\hline DH5 $\alpha$ & F- recA lacZAM15 & Bethesda Research Laboratories \\
\hline BL21-CodonPlus(DE3)-RIL & $\begin{array}{l}\mathrm{F}-\text { ompT hsdS }(\mathrm{rB}-\mathrm{mB}-) d c m+\mathrm{Tc}^{\mathrm{r}} \text { gal } \lambda(\mathrm{DE} 3) \text { endA Hte }[\arg U \text { ileY } \\
\left.\quad \text { leuW } \mathrm{Cam}^{\mathrm{r}}\right]\end{array}$ & Stratagene \\
\hline \multicolumn{3}{|l|}{ Ralstonia solanacearum } \\
\hline GMI1000 & Wild type & Boucher et al. (1985) \\
\hline GMI1402 & Tn5-B20::hrpV mutant & Arlat et al. (1992) \\
\hline GMI1410 & Tn5-B20::hrpY mutant & Arlat et al. (1992) \\
\hline GMI1525 & $h r p B:: \Omega$ mutant & Genin et al. (1992) \\
\hline GMI1575 & $\operatorname{prh} A: \because \Omega$ mutant & Marenda et al. (1998) \\
\hline GMI1578 & $h r p G:: \Omega$ mutant & Brito et al. (1999) \\
\hline GMI1658 & 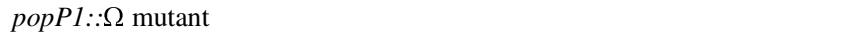 & This work \\
\hline GMI1695 & Mutant in upstream popPl ORFs in the ACUR & This work \\
\hline GMI1696 & Mutant in downstream popPl ORFs in the ACUR & This work \\
\hline $\mathrm{Rd} 15$ & Wild type & S. T. Hsu, A.V.R.D.C., Tainan, Taiwan \\
\hline \multicolumn{3}{|r|}{ te } \\
\hline $\mathrm{pHP} 45 \Omega$ & $\mathrm{Sp}^{\mathrm{r}}, \mathrm{Sm}^{\mathrm{r}}, \Omega$ & Prentki and Krisch (1984) \\
\hline pLAFR6 & pLAFR1 with $\operatorname{trp}$ terminators, $\mathrm{Tc}^{\mathrm{r}}$ & Huynh et al. (1989) \\
\hline pCZ205 & pUC19 carrying $l a c Z$ in $K p n I-X b a I, A m p{ }^{r}$ & This work \\
\hline pGEM-T & Cloning vector, $\mathrm{Amp}^{\mathrm{r}}$ & Promega \\
\hline pbluescript II SK(-) & $A m p^{r}$ & Stratagene \\
\hline pGMI1957 & pLAFR6 carrying $h r p Q$ promotor/lac $Z$ fusion & Van Gijsegem et al. (1995) \\
\hline pGMI3622 & pLAFR6 carrying popP 1 promotor/lacZ fusion in HindIII-KpnI & This work \\
\hline pGMI3623 & pLAFR6 carrying a $2.08 \mathrm{~kb} H i n \mathrm{dIII}-K p n I$ fragment containing $p o p P 1$ gene & This work \\
\hline
\end{tabular}

\footnotetext{
${ }^{\mathrm{a}} \mathrm{Tc}=$ tetracyclin, $\mathrm{ORFs}=$ open reading frames, $\mathrm{ACUR}=$ alternative codon usage region, $\mathrm{Sp}=$ spectinomycin, $\mathrm{Sm}=$ streptomycin, and $\mathrm{Amp}=$ ampicillin.
} 
was directly cloned into the pGEM-T vector, giving the pGEM-TDU plasmid. The EcoRI-restricted $\Omega$ integron then was cloned into the EcoRI-digested pGEM-TDU. The resulting plasmid was linearized by $\mathrm{XbaI}$ digestion and used to transform $R$. solanacearum GMI1000.

In the three mutants thus generated, gene replacement was confirmed by Southern hybridization or PCR (data not shown).

\section{Plasmid constructions.}

Plasmid pCZ205 is a pUC19 derivative in which a fragment $X b a \mathrm{I}-K p n \mathrm{I}$ containing the Tn5-lacZ transposon (Simon et al. 1989) has been cloned.

Plasmid pGMI3622 is a pLAFR6 derivative (Huynh et al. 1989) carrying a lac $Z$ coding sequence placed under the control of the popPl promoter. The $p o p P 1$ promoter/lac $Z$ fusion was generated by cloning the 973-bp DNA fragment located immediately upstream of the popP1 start codon by PCR amplification with P1-HindIII and P2-XbaI primers, into the HindIIIXbaI-digested pCZ205 plasmid. The fragment HindIII-KpnI containing the popPl promotor/lac $Z$ fusion then was cloned into the HindIII-KpnI-digested pLAFR6 plasmid (Huynh et al. 1989), giving the pGMI3622 plasmid.

Plasmid pGMI3623 is a pLAFR6 derivative (Huynh et al. 1989) in which a $2.08-\mathrm{kb}$ fragment containing a popPl gene driven by its own promoter has been inserted between the HindIII and KpnI cloning sites. This insert was generated by PCR using primers P1-HindIII and P3-KpnI (5'GGTACCTCACGACTCCAGGGCATG-3') and strain GMI1000 genomic DNA as template.

\section{$\beta$-Galactosidase assays.}

$\beta$-Galactosidase activities in bacterial cultures grown in minimal medium at $28^{\circ} \mathrm{C}$ for $18 \mathrm{~h}$ were assayed as previously described by Arlat and associates (1992). Activities also were measured upon coculture with A. thaliana At-202 cell suspensions following the procedure described by Marenda and associates (1998).

\section{Plant cell cultures and bacterial-plant cell co-cultures.}

A. thaliana At-202 cell suspensions were grown in Gamborg B5 (Flow Laboratories) as previously described by Marenda and associates (1998).

\section{Plant tests.}

HR tests on tobacco leaves and pathogenicity assays on Arabidopsis ecotypes Col-5 and Nd-1, Petunia, or tomato plants were performed as previously described by Marenda and associates (1998). Wilting symptoms were scored daily using a disease index scale ranging from 0 to 4 according to the percentage of wilted leave: $(0=$ no wilt, $1=1$ to $25 \%, 2=26$ to $50 \%, 3=51$ to $75 \%, 4=>75 \%$ ) (Arlat and Boucher 1991).

\section{Production of antibodies.}

The popPl gene was amplified from the genomic DNA of $R$. solanacearum strain GMI1000 by PCR using primers 5'-GCTCTAGAATGAAAAGACTATTCAGA-3' and 5'-CGCGAAGCTTTCACGACTCCAGGGCATG-3'. The PCR fragment was digested with $X b a \mathrm{I}-H i n \mathrm{IIII}$ and ligated into similarly cleaved pRDS vector, a modified pET28 expression vector that furnished an Nterminal $\mathrm{His}_{6}$ tag. E. coli BL21(DE3)-RIL (Stratagene, La Jolla, CA, U.S.A.) cells were transformed and these produced recombinant PopP1 after induction with $1 \mathrm{mM}$ IPTG. PopP1 was expressed at a very high level as an insoluble protein. Cells were lysed by sonication in $50 \mathrm{mM}$ Tris, $\mathrm{pH}$ 8.0, $1 \%$ Triton $\mathrm{X}-100,10$ $\mathrm{mM}$ imidazole, and $50 \mathrm{mM} \mathrm{NaCl}$ (TIN buffer). Inclusion bodies were harvested by centrifugation $(15,000 \times g)$ and solubilized with $6 \mathrm{M}$ urea in TIN buffer. After centrifugation, the lysate was loaded onto a $5-\mathrm{ml} \mathrm{Ni}^{2+}$ affinity column (Pharmacia) preequilibrated with $6 \mathrm{M}$ urea in TIN buffer. After extensive washing, PopP1 was eluted with $300 \mathrm{mM}$ imidazole in $50 \mathrm{mM}$ Tris, $\mathrm{pH} 8,6$ $\mathrm{M}$ urea, and $50 \mathrm{mM} \mathrm{NaCl}$. Fractions containing the eluted protein were pooled, diluted 20 times in $20 \mathrm{mM}$ Tris, $\mathrm{pH} 7.5,0.1 \%$ sodium dodecyl sulfate (SDS), and concentrated to $0.5 \mathrm{mg} / \mathrm{ml}$, using Centriprep 10 (Amicon). This preparation was used to immunize rabbits according to Ausubel and associates (1990).

\section{Western Blots.}

Strain GMI1000 and derivatives were grown at $28^{\circ} \mathrm{C}$ for 20 $\mathrm{h}$ in MMG supplemented with Congo red $\left(100 \mu \mathrm{g} \mathrm{ml}^{-1}\right)$. Concentrated supernatant preparations (CSP) and cell-free lysates were obtained from these cultures as described by Guéneron and associates (2000), except that one-fourth of these CSP were used for SDS-polyacrylamide gel electrophoresis.

The PopA-specific antiserum used in this study has been described previously (Arlat and associates 1994). A commercial polyclonal antiserum (Sigma Aldrich, St. Louis) was used for the detection of $\beta$-galactosidase.

\section{ACKNOWLEDGMENTS}

This work was supported by the Toulouse Genopole and by a Grant Microbiologie 2000 from the French Ministry of Research. We thank C. Birck (J. P. Samama's group) for her expertise in the preparation of purified PopP1 antigen; personnel from the animal house of the Institut de Pharmacologie et de Biologie Structurale (Toulouse) for immunization of rabbits; P. Boistard and S. Genin for stimulating discussions; and J.-L. Pariente, C. Ischer, and L. Sauviac for help with preparation of plants.

\section{LITERATURE CITED}

Aldon, D., Brito, B., Boucher, C., and Genin, S. 2000. A bacterial sensor of plant cell contact controls the transcriptional induction of Ralstonia solanacearum pathogenicity genes. EMBO (Eur. Mol. Biol. Organ.) J. 19:2304-2314.

Arlat, M., and Boucher, C.A. 1991. Identification of a $d s p$ DNA region controlling aggressiveness of Pseudomonas solanacearum. Mol. PlantMicrobe Interact. 4:211-213.

Arlat, M., Gough, C. L., Zischek, C., Barberis, P. A., Trigalet, A., and Boucher, C. A. 1992. Transcriptional organization and expression of the large hrp gene cluster of Pseudomonas solanacearum. Mol. PlantMicrobe Interact. 5:187-193.

Arlat, M., Van Gijsegem, F., Pernollet, J. C., and Boucher C. A. 1994. PopA1, a protein which induces a hypersensitivity-like response on specific petunia genotypes, is secreted via the Hrp pathway of Pseudomonas solanacearum. EMBO (Eur. Mol. Biol. Organ.) J. 13:543-553.

Ausubel, F. M., Brent, R., Kingston, R. E., Moore, D. D., Seidman, J. G., Smith, J. A., and Struhl, K. 1990. Current Protocols in Molecular Biology. Green Publishing Associates and Wiley Interscience, New York.

Bogdanove, A. J., Bauer, D. W., and Beer, S. V. 1998. Erwinia amylovora secretes DspE, a pathogenicity factor and functional AvrE homolog, through the Hrp (type III secretion) pathway. J. Bacteriol. 180:22442247.

Boucher, C. A., Barberis, P., Trigalet, A. P., and Démery, D. A. 1985. Transposon mutagenesis of Pseudomonas solanacearum: Isolation of Tn5-induced avirulent mutants. J. Gen. Microbiol. 131:2449-2457.

Brito, B., Aldon, D., Barberis, P., Boucher, C., and Genin, S. 2002. A signal transfer system through three compartments transduces the plant cell contact-dependent signal controlling Ralstonia solanacearum hrp genes. Mol. Plant-Microbe Interact. 15:109-119.

Brito, B., Marenda, M., Barberis, P., Boucher, C., and Genin, S. 1999. prhJ and $h r p G$, two new components of the plant signal-dependent regulatory cascade controlled by PrhA in Ralstonia solanacearum. Mol. Microbiol. 31:237-251.

Carney, B. R., and Denny, T. P. 1990. A cloned avirulence gene from Pseudomonas solanacearum determines incompatibility on Nicotiana tabacum at the host species level. J. Bacteriol. 172:4836-4843.

Casper-Lindley C., Dahleck, D., Clark, E., Staskawicz, B. 2002. Direct biochemical evidence for the type III secretion-dependent translocation of the AvrBs2 effector protein into plant cells. Proc. Natl. Acad. Sci. U.S.A. 99:8336-8341.

Cheetham, B. F., and Katz, M. E. 1995. A role for bacteriophages in the evolution and transfer of bacterial virulence determinants. Mol. 
Microbiol. 18:201-208.

Ciesiolka, L. D., Hwin, T., Gearlds, J. D., Minsavage, G. V., Saenz, R., Bravo, M., Handley, V., Conover, S. M., Zhang, H., Caporgno, J., Phengrasamy, N. B., Toms, A. O, Stall, R. E., and Whalen, M. C. 1999. Regulation of expression of avirulence gene $a v r R x v$ and identification of a family of host interaction factors by sequence analysis of $a v r B s T$. Mol. Plant-Microbe Interact. 12:35-44.

Cornelis, G. R., and Van Gijsegem, F. 2000. Assembly and function of type III secretory systems. Annu. Rev. Microbiol. 54:735-74

Corpet, F. 1988. Multiple sequence alignment with hierarchical clustering. Nucleic Acids Res. 16:10881-10890.

Denecker, G., Declercq, W., Geuijen, C. A., Boland, A., Benabdillah, R., Van Gurp, M., Sory, M. P., Vandenabeele, P., and Cornelis, G. R. 2001. Yersinia enterocolitica YopP-induced apoptosis of macrophages involves the apoptotic signaling cascade upstream of bid. J. Biol. Chem. 276:19706-19714.

Deslandes, L., Olivier, J., Theulieres, F., Hirsch, J., Feng, D. X., Bittner, E. P., Beynon, J., and Marco, Y. 2002. Resistance to Ralstonia solanacearum in Arabidopsis thaliana is conferred by the recessive $R R S 1-R$ gene, a member of a novel family of resistance genes. Proc. Natl. Acad. Sci. U.S.A. 99:2404-2409.

Deslandes, L., Pileur, F., Liaubet, L., Camut, S., Can, C., Williams, K., Holub, E., Beynon, J., Arlat, M., and Marco, Y. 1998. Genetic characterization of RRS1, a recessive locus in Arabidopsis thaliana that confers resistance to the bacterial soilborne pathogen Ralstonia solanacearum. Mol. Plant-Microbe Interact. 11:659-667.

Ezra, D., Barash, I., Valinsky, L., and Manulis, S. 2000. The dual function in virulence and host range restriction of a gene isolated from the pPA$\mathrm{TH}_{\mathrm{Ehg}}$ plasmid of Erwinia herbicola pv. gypsophilae. Mol. PlantMicrobe Interact. 13:683-692.

Galan, J. E., and Collmer, A. (1999) Type III secretion machines: Bacterial devices for protein delivery into host cells. Science 284:1322-1328.

Gaudriault, S., Malandrin, L., Paulin, J. P., and Barny, M. A. 1997. DspA, an essential pathogenicity factor of Erwinia amylovora showing homology with AvrE of Pseudomonas syringae, is secreted via the Hrp secretion pathway in a DspB-dependent way. Mol. Microbiol. 26:1057-1069.

Genin, S., Gough, C. L., Zischek, C. and Boucher, C. A. 1992. The hrpB gene encodes a positive regulator of pathogenicity genes from Pseudomonas solanacearum. Mol. Microbiol. 6:3065-3076.

Guéneron, M., Timmers, A. C., Boucher, C., and Arlat, M. 2000. Two novel proteins, PopB, which has functional nuclear localization signals, and $\mathrm{PopC}$, which has a large leucine-rich repeat domain, are secreted through the hrp-secretion apparatus of Ralstonia solanacearum. Mol. Microbiol. 36:261-277.

Hacker, J., Blum-Oehler, G., Muhldorfer, I., and Tschape, H. 1997. Pathogenicity islands of virulent bacteria: Structure, function and impact on microbial evolution. Mol. Microbiol. 23:1089-1097.

Heidelberg J. F., Eisen, J. A., Nelson, W. C., Clayton, R. A., Gwinn, M. L., Dodson, R. J., Haft, D. H., Hickey, E. K., Peterson, J. D., Umayam, L. A., Gill, S. R., Nelson, K. E., Read, T. D., Tettelin, H., Richardson, D., Ermolaeva, M. D., Vamathevan, J., Bass, S., Qin, H., Dragoi, I., Sellers, P., McDonald, L., Utterback, T., Fleischmann; R. D., Nierman, W. C., White, O., Salzberg, S. L., Smith, H. O., Colwell, R. R., Mekalanos, J. J., Venter, J. C., and Fraser, C. M. 2000. DNA sequence of both chromosomes of the cholera pathogen Vibrio cholerae. Nature 406:477-483.

Higuchi, R. 1990. Recombinant PCR. Pages 177-183 in: PCR Protocols: A Guide to Methods and Applications. M. A. Innis, D. H. Gelfand, J. J. Sninsky, and T. J. White, eds. Academic Press, New York.

Hueck, C. J. 1998. Type III protein secretion systems in bacterial pathogens of animals and plants. Microbiol. Mol. Biol. Rev. 62:379-433.

Huynh, T. V., Dahlbeck, D., and Staskawicz, B. J. 1989. Bacterial blight of soybean: Regulation of a pathogen gene determining host cultivar specificity. Science 245:1374-1377.

Keen, N. 1990. Gene-for-gene complementarity in plant-pathogen interactions. Annu. Rev. Genet. 24:447-463.

Komine, Y., Kitabatake, M., Yokogawa, T., Nishikawa, K., and Inokuchi, H. 1994. A tRNA-like structure is present in 10Sa RNA, a small stable RNA from Escherichia coli. Proc. Natl. Acad. Sci. U.S.A. 91:9223-9227.

Kovach, M. E., Shaffer, M. D., and Peterson, K. M. 1996. A putative integrase gene defines the distal end of a large cluster of ToxR-regulated colonization genes in Vibrio cholerae. Microbiology 142:2165-2174.

Lahaye, T., and Bonas, U. 2001. Molecular secrets of bacterial type III effector proteins. Trends Plant Sci. 6:479-485.

Lahaye, T., Szurek, B., Marois, E., Schornack, S., Jordan, T., Büttner, D., Escolar, L., Thieme, F., Noël, L., and Bonas, U. 2002. Role of type III effector proteins from Xanthomonas in the interaction with the plant. Pages 135-145 in: Biology of Plant-Microbe Interactions. Vol. 3. S. Leong, C. Allen, and E. Triplett, eds. APS Press, St. Paul, MN, U.S.A

Mangin, B., Thoquet, P., Olivier, J., and Grimsley, N. H. 1999. Temporal and multiple quantitative trait loci analyses of resistance to bacterial wilt in tomato permit the resolution of linked loci. Genetics 151:1165-1172.

Marenda, M., Brito, B., Callard, D., Genin, S., Barberis, P., Boucher, C., and Arlat, M. 1998. PrhA controls a novel regulatory pathway required for the specific induction of Ralstonia solanacearum hrp genes in the presence of plant cells. Mol. Microbiol. 27:437-453.

Orth, K. 2002. Function of the Yersinia effector YopJ. Curr. Opin. Microbiol. 5:38-43.

Orth, K., Xu, Z., Mudgett, M. B., Bao, Z. Q., Palmer, L. E., Bliska, J. B., Mangel, W., Staskawicz, B., and Dixon, J. E. 2000. Disruption of signaling by Yersinia effector YopJ, a ubiquitin-like protein protease. Science 290:1594-1597.

Prentki, P., and Krisch, H. M. 1984. In vitro insertional mutagenesis with selectable DNA fragment. Gene 29:303-313.

Salanoubat, M., Genin, S., Artiguenave, F., Gouzy, J., Mangenot, S., Arlat, M., Billault, A., Brottier, P., Camus, J. C., Cattolico, L., Chandler, M. , Choisne, N., Claudel-Renard, C., Cunnac, S., Demange, N., Gaspin, C., Lavie, M., Moisan, A., Robert, C., Saurin, W., Thébault, P., Schiex, T., Siguier, P., Whalen, M., Wincker, P., Levy, M., Weissenbach, J., and Boucher, C. A. 2002. Genome sequence of the plant pathogen Ralstonia solanacearum. Nature 415:747-502.

Sambrook, J., Fritsch, E. F., and Maniatis, T. 1989. Molecular Cloning: A Laboratory Manual. 2nd ed. Cold Spring Harbor Laboratory Press, Cold Spring Harbor, NY, U.S.A.

Simon, R., Quandt, J., and Klipp, W. 1989. New derivatives of transposon Tn5 suitable for mobilization of replicons, generation of operon fusions and induction of genes in gram-negative bacteria. Gene 80:161-169.

Staskawicz, B. J, Mudgett, M. B., Dangl, J. L., and Galan, J. E. 2001. Common and contrasting themes of plant and animal diseases. Science 292:2285-2289.

Van Gijsegem, F., Gough, C., Zischek, C., Niqueux, E., Arlat, M., Genin, S., Barberis, P., German, S., Castello, P., and Boucher, C. 1995. The hrp gene locus of Pseudomonas solanacearum, which controls the production of a type III secretion system, encodes eight proteins related to components of the bacterial flagellar biogenesis complex. Mol. Microbiol. 15:1095-1114.

Vasse, J., Genin, S., Frey, P., Boucher, C., and Brito, B. 2000. The hrpB and $h r p G$ regulatory genes of Ralstonia solanacearum are required for different stages of the tomato root infection process. Mol. PlantMicrobe Interact. 13:259-267.

Wang, J.-F., Olivier, J., Thoquet, P., Mangin, B., Sauviac, L., and Grimsley, N. H. 2000. Resistance of tomato line Hawaii7996 to Ralstonia solanacearum Pss4 in Taiwan is controlled mainly by a major strain-specific locus. Mol. Plant-Microbe Interact. 13:6-13.

White, F. F., Yang, B., and Johnson, J. B. 2000. Prospects for understanding avirulence gene function. Curr. Opin. Plant Biol. 3:291-298.

Wood, M. S., Byrne, A., and Lessie, T. G. 1991. IS406 and IS407, two gene-activating insertion sequences for Pseudomonas cepacia. Gene 105:101-105

\section{AUTHOR-RECOMMENDED INTERNET RESOURCE}

Ralstonia solanacearum strain GMI100 annotated complete genome sequence: http://sequence.toulouse.inra.fr/R.solanacearum. 